\title{
EEG AND DEMENTIA INDICATORS IN AIDS PATIENTS' RORSCHACH TEST
}

\author{
G. FERNANDES DO PRADO*, L.B.C. CARVALHO**, A. BAPTISTA DA SILVA***, J.G.C. LIMA****
}

\begin{abstract}
SUMMARY - We studied the EEG and Rorschach test (RT) of nineteen AIDS patients and eight normal people in the same age group. Eight patients presented slow alpha rhythms $(8$ to $9 \mathrm{~Hz})$; three, not-slow alpha rhythms $(>9$ to $13 \mathrm{~Hz}$ ); and eight, beta rhythms in background activity. Paroxystic activity, characterized by diffuse theta or delta waves, was present in eleven patients. We observed Oberholzer syndrome (organic dementia diagnosed by RT) in ten patients and Piotrowski syndrome (organic dementia diagnosed by RT) in eleven patients; six presented both. When considering only the group of AIDS patients, we did not observe a significant relation among slow alpha rhythm, not-slow alpha rhythm and the presence of paroxystic activity with the abovementioned syndromes. AIDS patients with slow alpha rhythms showed a significantly greater number of Piotrowski syndrome dementia indicators when compared to normal individuals or those with slow alpha rhythms. We did not observe the same with Oberholzer syndrome.
\end{abstract}

KEY WORDS: dementia, AIDS, HIV infection, EEG, Rorschach test.

\section{EEG e indicadores de demência no teste de Rorschach em pacientes com AIDS}

RESUMO - Realizou-se EEG e teste psicodiagnóstico de Rorschach (TR) em dezenove pacientes aidéticos e em oito pessoas normais na mesma faixa etária. Oito pacientes apresentaram alfa lento, três alfa não lento e oito ritmo beta na atividade de base. A atividade paroxística esteve presente em onze pacientes, tendo sido caracterizada por ondas teta ou delta difusas. A síndrome de Oberholzer (demência orgânica observada através do RT) foi observada em dez pacientes e a síndrome de Piotrowski (demência orgânica observada através do RT) em onze pacientes; seis pacientes apresentaram as duas síndromes. Não se observou relação entre ritmo alfa lento, alfa não lento e presença de atividade paroxística com as referidas síndromes, quando se considerou apenas o grupo de pacientes aidéticos. Os pacientes aidéticos com ritmo alfa lento apresentaram número significantemente maior de indicadores da síndrome de Piotrowski quando comparados às pessoas normais e com alfa lento, não se demonstrando o mesmo em relação à síndrome de Oberholzer.

PALAVRAS- CHAVE: demência, AIDS (SIDA), infecção por HIV, EEG, teste de Rorschach.

Acquired immunodeficiency syndrome (AIDS) is caused by HIV, a retrovirus that infects CD4+ cells, and is characterized by progressive immunological deficit because of its cytopathic effects on T4 lymphocytes ${ }^{5,15,18}$. It evolves with serious opportunistic systemic and neurological complications ${ }^{1}$. The nervous system (NS) is frequently affected by this syndrome. The first signs and symptoms often result from its debilitation ${ }^{23.24}$. AIDS dementia complex (ADC) - a psycho-organic syndrome characterized by cognitive (attention, perception, memory and judgment), behavioral (taskexecution ability, daily activity and conduct), motor coordination and mood alterations ${ }^{21}$ - is the

Discipline of Neurology, Escola Paulista de Medicina (EPM) and Institute of Psychology, Universidade de São Paulo (USP): *Pós-graduando da Disciplina de Neurologia, EPM; **Pós-graduanda do Instituto de Psicologia, USP; ***Professor Adjunto da Disciplina de Neurologia, EPM; ****Professor Titular e Chefe da Disciplina de Neurologia, EPM. Aceite: 23-janeiro-1994.

Dr. Gilmar Fernandes do Prado - Rua Santa Flora 244 - 01549-040 São Paulo SP - Brasil. 
most frequent neurological problem. It has been observed since the first AIDS cases and was described in detail by Navia et al. in 1986 14,23,24,29. ADC can be classified as mild (independent life, cognitive impairment or objective deficit in at least one cognitive area), moderate (deficit in two or more cognitive areas with continued ability to do simple daily activities) and severe (global cognitive impairment with severe disability: being bedridden, intellectual and social limitation, and total dependency ${ }^{23,24,29}$. Pathophysiologically, ADC is related to multiple foci of gliosis in the cerebral cortex and mainly subcortical white matter. In addition, neuronal loss and the effect of viral proteins like GP120 which compete with peptides (such as VIP and neuroleucine) for neurotrophic receptors cause neuronal death due to increased influx of calcium to the neuron ${ }^{6-8,17,30}$.

The EEG, a simple noninvasive examination, shows alterations that have been attributed to HIV since the beginning ${ }^{9,11}$. The main alteration observed is background rhythm slowing, seen in the lower alpha range or in the theta range, with a correlation between this finding and progressive immunosuppression or systemic complications and diffuse paroxystic activity (PA) presence ${ }^{10,12,28,32-34}$. Psychological tests have been useful for defining and characterizing ACD, normally being tests to evaluate specific cognition areas like verbal memory, attention, vocabulary, perception speed $^{31}$, and visual and auditory perception association ${ }^{13}$. The Rorschach test (RT) is a good instrument for diagnosing organic syndromes, differing them from those that are purely psychological ${ }^{3}$. Rorschach organic syndrome can be differentiated by two types, Oberholzer syndrome ${ }^{25}$ (OS) and Piotrowski syndrome $^{26}$ (PS), which consider a set of symptoms related to personality alterations caused by neurological debilitation leading to dementia. OS accents cognitive function loss, differentiating forms of dementia, schizophrenia and oligophrenia. PS accents insight, disregarding global responses that are poorly viewed and the type of extratensive lifestyle, both of which would express a lack of capacity for self control and abstract reasoning, placing importance on indicators related to selfcritical judgment in terms of test performance (insecurity, feelings of impotence, stereotyped expression, critical reasoning and need for confirmation).

The subject of this study is to evaluate the correlation between EEG (mainly background activity) and RT's dementia indicators to verify their diagnostic value on AIDS encephalopathy.

\section{MATERIAL AND METHOD}

We studied EEG (background rhythm and paroxystic activity) and Rorschach test demential indicators (Oberholzer and Piotrowski syndromes) in nineteen patients with HIV infection and eight normal people in the same age group. The latter eight presented slow background rhythm $(8$ to $9 \mathrm{~Hz})$ and served as the control group for the eight AIDS patients also having slow background rhythm.

Seventeen patients were male and two, female. All were from nineteen to fifty-four years of age. As for the risk group, eight were homosexuals; three, bisexuals; two, drug addicts; one, hemophiliac and five were undetermined. Eighteen patients were in CDC group IV and one in CDC group II (patient number 7, Table 1). All patients were neurologically evaluated and clinically classified in EI (encephalic involvement), NEI (nonencephalic involvement, though having abnormal neurological evaluation due to peripheral and/or muscular alterations) and NN (normal neurologic evaluation). They underwent EEG examinations, according to IFSECN ${ }^{16}$ standards, using Berger ED 121 and Meditron equipment. All were admitted to a hospital for treatment or diagnostic testing and the RT was administered at bedside.

Background rhythm was visually measured using a millimetric ruler in the posterior areas. When there was a variation in frequency, we always considered the greater. Background rhythm was classified as slow alpha $(8 \text { to } 9 \mathrm{~Hz})^{9}$, not-slow alpha $(>9 \mathrm{~Hz}$ to $13 \mathrm{~Hz})$ and beta $(>13 \mathrm{~Hz})$. Paroxystic activity was interpreted as being any diffuse burst of theta or delta waves with an abrupt beginning and end ${ }^{16}$ not attributable to somnolence.

Demential indicators based on the $\mathrm{RT}^{3}$ were evaluated according to fifteen Oberholzer syndrome indicators (OSI): increased reaction time, type of extratensive lifestyle, little capacity for affective adaptation (EF e E), few readily acceptable answers $(\mathrm{F}+\%)$, few primary global answers $(\mathrm{G}+)$, presence of poorly-viewed global $(\mathrm{G}-)$ and contaminated answers (DG), more answers with small details (Dd), few detailed answers (D), more answers having animal content $(\mathrm{A} \%)$, poorly-viewed original answers (O-), few human movement answers (K), 
Table 1. Clinical data, EEG and demential indicators.

\begin{tabular}{|c|c|c|c|c|c|c|c|c|c|c|}
\hline $\mathrm{N}^{\circ}$ & $\mathbf{S}$ & AG & RG & NI & $\mathrm{CDC}$ & $\mathrm{BR}$ & PA & ODI (15) & PDI (10) & DIAG \\
\hline 1 & $\mathbf{M}$ & 28 & $\mathbf{H}$ & $\mathrm{NN}$ & IV & 12 & - & 5 & 5 & PS \\
\hline 2 & $\mathbf{M}$ & 38 & $\mathrm{H}$ & NEI & IV & 8 & - & 3 & 3 & ND \\
\hline 3 & $\mathbf{M}$ & 34 & B & EI & IV & $>13$ & theta & 5 & 3 & ND \\
\hline 4 & $\mathrm{~F}$ & 26 & U & EI & IV & 8 & theta & 9 & 5 & OS/PS \\
\hline 5 & $\mathbf{M}$ & 33 & $\mathrm{H}$ & EI & IV & 9 & $\begin{array}{l}\text { theta } \\
\text { delta }\end{array}$ & 6 & 7 & PS \\
\hline 6 & $\mathbf{F}$ & 30 & $\mathrm{DA}$ & NEI & IV & $>13$ & delta & 9 & 7 & OS/PS \\
\hline 7 & $\mathbf{M}$ & 19 & $\mathrm{U}$ & NN & II & 8 & delta & 3 & 4 & ND \\
\hline 8 & $\mathbf{M}$ & 34 & $\mathrm{U}$ & NN & IV & $>13$ & - & 8 & 5 & OS/PS \\
\hline 9 & $\mathbf{M}$ & 43 & $\mathrm{HE}$ & $\mathrm{NN}$ & IV & $>13$ & - & 9 & 5 & OS/PS \\
\hline 10 & $\mathbf{M}$ & 33 & $\mathrm{H}$ & NEI & IV & 9 & - & 7 & 4 & os \\
\hline 11 & $\mathbf{M}$ & 23 & $\mathrm{H}$ & EI & IV & 8 & $\begin{array}{l}\text { theta } \\
\text { delta }\end{array}$ & 8 & 6 & OS/PS \\
\hline 12 & $\mathbf{M}$ & 28 & $\mathrm{H}$ & EI & IV & $>13$ & theta & 6 & 5 & PS \\
\hline 13 & $\mathbf{M}$ & 28 & $\mathrm{U}$ & $\mathrm{NN}$ & IV & 8 & - & 3 & 4 & ND \\
\hline 14 & $\mathbf{M}$ & 31 & $\mathbf{H}$ & NEI & IV & 9 & - & 7 & 7 & OS/PS \\
\hline 15 & $\mathbf{M}$ & 19 & $\mathrm{DA}$ & $\mathrm{NN}$ & IV & 11 & theta & 6 & 5 & PS \\
\hline 16 & $\mathbf{M}$ & 54 & $\mathrm{H}$ & $\mathrm{NN}$ & IV & $>13$ & - & 8 & 4 & OS \\
\hline 17 & $\mathbf{M}$ & 28 & $\mathrm{U}$ & EI & IV & $>13$ & delta & 6 & 4 & os \\
\hline 18 & $\mathbf{M}$ & 35 & B & EI & IV & $>13$ & $\begin{array}{l}\text { theta } \\
\text { delta }\end{array}$ & 9 & 6 & OS/PS \\
\hline 19 & $\mathbf{M}$ & 33 & B & EI & IV & 10 & theta & 5 & 2 & ND \\
\hline
\end{tabular}

S, sex; AG, age; RG, risk group; NI, neurological involvement; CDC, Center for Disease Control groups; BR, background rhythm; PA, paroxystic activity; ODI, Oberholzer demential indicators; PDI, Piotrowski demential indicators; DIAG, dementia diagnostic; M, male; F, female; $H$, homosexuals; B, bisexual; $U$, undetermined; DA, drug addicts; HE, hemophiliac; NN, normal neurologic examination; NEI, nonencephalic involvement; EI, encephalic involvement; ND, non dement.

confabulated answers, tendency for perseverance, repetition and self-criticism; and according to ten Piotrowski syndrome indicators (PSI): fewer than 15 answers (R), increased reaction time (more than one minute per answer), no or one human movement answer (K), named-color answer $(\mathrm{Cn})$, fewer than $70 \%$ well-viewed answers $(\mathrm{F}+)$, fewer than $25 \%$ banal answers (Ban), perseverance, insecurity (needing confirmation), impotence in light of inadequate answers, stereotyped expressions (automatic phrases). Patients with $50 \%$ (or more) of the indicators (OSI $>=7$ or PSI $>=5$ ) were considered to have organic demential syndrome ${ }^{25,26}$.

\section{RESULTS}

We studied nineteen patients, eight (42\%) presented slow alpha rhythms; three (16\%), not-slow alpha rhythms; eight $(42 \%)$, beta rhythms and eleven $(73 \%)$ difuse theta and/or delta rhythm with anterior predomination. In eight slow alpha rhythm patients, four presented with OS and four with PS. In three not-slow alpha rhythm patients, two presented with PS.

We observed eight patients with beta rhythm, seven of them (89\%) presented one form of dementia on RT (six presented with OS and five presented with PS).

Patients 4, 6, 8, 9, 11, 14 and 18 (Table 1) presented both OS and PS.

OS and PS showed no relation to the presence of slow and not-slow alpha rhythms, nor to the presence or absence of diffuse paroxystic activity in the nineteen AIDS patient group ( $\mathrm{p}=66.41 \%$ ). In eleven patients with diffuse paroxystic activity, eight (73\%) have any form (OS and/or PS) of RT organic dementia. 
Table 2. Piotrowski syndrome demential indicators in AIDS patients with slow background rhythm and normal people in the same age group.

\begin{tabular}{ccc}
\hline & \multicolumn{2}{c}{ PS Indicators } \\
\cline { 2 - 3 } & AIDS Patients & Normal People \\
\hline 3 & 4 \\
5 & 4 \\
7 & 3 \\
4 & 2 \\
4 & 6 \\
& 6 & 1 \\
& 4 & 3 \\
$\mathrm{X}=$ & 7 & 3 \\
& 5,00 & 3,25 \\
\hline
\end{tabular}

The groups differ significantly. Mann-Whitney test $(\mathrm{p}=3.79 \%)$.
Distribution of OS indicators in AIDS patients with slow background rhythm and non-AIDS patients with slow background rhythms showed that there was no difference between the groups, though there was a statistical difference $(\mathrm{p}=3.79 \%)$ in relation to PS (Table 2).

Considering the entire sample (19 patients), we had five normal patients, ten cases with OS and eleven cases with PS (57.89\%).

\section{COMMENTS}

We studied nineteen AIDS patients using EEG and RT examinations (Table 1). RT was adequate for evaluating demential syndrome, as it is an easily applied projective test - usable with bedridden patients. It is being used evermore frequently for neuropsychological diagnosis ${ }^{2}$. This increased use is because the test permits more detailed cognitive evaluation than other projective tests, while, at the same time, allows us to evaluate the patient's emotional state, which is not considered in tests measuring cognitive and practical conditions. Being a projective test, RT decreases the patient's performance expectation, thus preventing test situation stress from interfering in his performance. Furthermore, application does not depend on the patient's age or his social, economic and educational background.

The RT classified nearly half of the group studied as presenting dementia. OS criteria is more sensitive in detecting changes in the cognitive process (deficit of judgement, memory, stimuli perception), slow thought, self-criticism and insecurity of performance, all of which have previously been mentioned ${ }^{21}$. Oberholzer syndrome has more detailed criteria in relation to practical, adaptative and constructive intelligence, presenting items that can also be related to other pathological groups. Piotrowski syndrome is made up of items related to general and adaptative intelligence, choosing criteria that differentiate demential syndrome from others.

Dementia in AIDS patients was recognized and attributed to action by HIV even before Navia et al. described the AIDS demential complex in $1986^{23}$. Several possibilities have been discussed to pathophysiologically explain this process. These involve action by viral capsule (gp120), which competes with neuropeptides like VIP (vasoactive intestinal peptide) and peptide T, and neuronal death through cytotoxic mechanism mediated by calcium ${ }^{4,7,8,17,30}$. Studies carried out since Navia et al. ${ }^{23}$ demonstrate a rate of incidence of the same in from 10 to $70 \%$ of AIDS cases, with dementia potentially being present (or subclinical) in $92 \%$ of cases during the illness' final stage ${ }^{20,23,24,29}$. There are many disputes regarding this data, with the manner of classifying patients being rather heterogeneous, reiterating that neuropsychological alterations and EEG may indicate this syndrome's early existence.

AIDS patients' EEG background rhythm has been studied since 1985 by Enzensberger et al. These authors observed that approximately $50 \%$ of their patients presented alpha rhythm between 8 to $9 \mathrm{~Hz}$, which is observed in only $15 \%$ of the normal adult population ${ }^{9}$. Other studies also concluded that there was a high percentage of slow alpha in these patients also, having been classified borderline $\mathrm{EEGs}^{22,27,28,34}$.

In our group of nineteen patients, eleven (58\%) presented with PA on EEG; this was not statisticaly significant $(\mathrm{p}=66.41 \%)$. In eleven patients with $\mathrm{PA}$, there were eight demented patients 
(73\%), demonstrating a close relation with RT organic dementia. Diffuse paroxystic activity is common in patients of CDC group IV ${ }^{34}$, but further controlled studies are necessary to clarify this question.

In eigth patients with beta rhythm, seven (89\%) presented with OS and/or PS on RT. This observation, as well as beta rhythm on EEGs of AIDS patients, is not refered on specialized literature and will be object of our future publication. Beta rhythm may be an expression of poor alpha rhythm production capacity, another possible EEG effect of central nervous system HIV infection.

Meningitis, toxoplasmosis or even mental conditions such as depression and psychosis can make diagnosis of dementia as the group it represents difficult since the above-mentioned illnesses can equally present cognitive and practical alterations. However, in the Prado study ${ }^{27}$, cerebral toxoplasmosis patients' EEG background rhythm was approximately $0.5 \mathrm{~Hz}$ higher than in demential patients without cerebral toxoplasmosis or other neurological complications ${ }^{27}$.

AIDS patients studied using neuropsychological tests, magnetic resonance and EEG have shown EEG alteration earlier than any of the above procedures ${ }^{19,22}$.

In our study, RT proved useful for ADC diagnostics, both through OS and PS indicators. EEG - showing slow alpha rhythm in $42 \%$ of patients, which systematically has been related to HIV action in the CNS - has also proved useful.

Acknowledgement - We gratefully acknowledge William Shelton for his help in revising this text.

\section{REFERENCES}

1. Anders KH, Guerra WF, Tomiyasu U, Verity MA, Vinters AV. The neuropathology of AIDS: UCLA experience and review. Am J Pathol 1986, 124: 537-558.

2. Bizari L, Souza MA. Rorschach em aidéticos. Encontro Brasileiro de Rorschach, São Paulo,1988: Resumos. São Paulo, 1989.

3. Bohm E. Psicosis orgânicas. In BOHM E. Manual del psicodioagnóstico de Rorschach, Ed 8, Madrid: Ediciones Morata 1984, p 356-368.

4. Brenneman DE, Westbrook GL, Fitzgerald SP, Ennist DL, Elkins KL, Ruff MR, Pert CB. Neuronal cell killing by the envelop protein of HIV and its prevention by vasoactive intestinal peptide. Nature 1988, 335: 639-642.

5. Dalgleish AG, Beverley PC, Clapham RP, Crawford DH, Greaves MF, Weiss RA. The CD4 (T4) antogen is an essential component of the receptor for the AIDS retrovirus. Nature 1984, 312: 763-767.

6. De La Monte SM, Ho DD, Schooley RT, Hirsch MS, Richardson EP. Subacute encephalomyelitis of AIDS and its relation to HTLV-III infection. Neurology 1987, 37: 562-569.

7. Dreyer EB, Kaiser PK, Offermann JT, Lipton SA. HIV-1 coat protein neurotoxicity prevented by calcium channel antagonists. Science 1990, 248: 364-367.

8. Everall IP, Luthert PJ, Lantos PL. Neuronal loss in the frontal cortex in HIV infection. Lancet 1991, 337: $1119-1121$.

9. Enzensberger W, Fischer PA, Helm EB, Stille W. Value of electroencephalography in AIDS. Lancet 1985, 4: 1047-1048.

10. Enzensberger W, Helm EB, Fischer PA. EEG follow-up examination in AIDS patients. Electroenceph Clin Neurophysiol 1986, 63:28P.

11. Fischer PA, Enzensberger W. Neurological complications in AIDS. J Neurol 1987, 234: 269-279.

12. Gabuzda DH, Levy SR, Chiappa KH. Electroencephalography in AIDS and AIDS-related complex. Clin Electroenceph 1988, 19: 1-6.

13. Grant I, AtkinsonH, Hesselink JR, Kennedy CJ, Richman DD, Spector SA, McCutchan JA. Evidence for early central nervous system involvement in acquired immunodeficiency syndrome (AIDS) and other human immunodeficiency virus (HIV) infections. Ann Intern Med 1987, 107: 828-836.

14. Gray F, Gherardi R, Poirier J. Les lésions du systeme nerveux au cours du SIDA. Arch Anat Cytol Path 1986, 34: 268-278.

15. Hamburg MA, Koening S, Fauci AS. Immunology of AIDS and HIV infection. In Mandell GL. Principles and practises of infections diseases and their etiology agents. Part II, Vol I, Section P. Ed 3. New York: Churchill Livingstone, 1990, p 1046-1058. 
16. Ifsecn. A glossary of terms most commonly used by clinical electroencephalographers. Electroenceph Clin Neurophysiol 1974, 37: 538-548.

17. Ketzler S, Weis S, Haug H, Budka H. Loss of neurons in the frontal cortex in AIDS brains. Acta Neuropathol 1990, 80: 92-94.

18. Klatzmann D, Champagne E, Chamaret S, Gruest J, Guetard D, Hercend T, Cluckman JC, Montagnier L. Tlymphocyte T4 molecule behaves as the receptor for human retrovirus LAV. Nature 1984, 312: 767.

19. Koralnik, Beaumandir A, Hausler R, Kholer A, Delacoux R, Hirschel B. Abnormalities of EEG and otoneurologic test in asymptomatic HIV infected homosexuals: a prospective controlled study. $\mathrm{V}^{\mathrm{E}}$ Conférence Internationale sur le SIDA. Montreal, 1989. Abregés. Montreal, 1989, p 462.

20. Levy RM, Bredesen DE, Rosenblun ML. Neurological manifestations for the acquired immunodeficiency syndrome (AIDS): experience at UCSF and review of the literature. J Neurosurg 1985, 62: 475-495.

21. Link D. AIDS dementia complex. Treatment Issues 2, Vol. VI, 1992.

22. Minoli L, Nappi G. EEG findings and cognitive performance in $82 \mathrm{HIV}$-infected patients. $\mathrm{V}^{\mathrm{E}}$ Conférence Iinternationale sur le SIDA. Montreal, 1989. Abregés. Montreal, 1989, p 462.

23. Navia BA, Jordan BD, Price RW. The AIDS dementia complex: I. Clinical features. Ann Neurol 1986, 19: 517-524.

24. Navia BA, Cho ES, Petito CK, Price RW. The AIDS dementia complex: II. Neuropathology Ann Neurol 1986, 19: 525-535.

25. Oberholzer E. Zur differentialdiagnose psychicher Folgezustande nach Schadeltraumen mittels des Rorschachschen Formdeutversuchs. Zges Neurol Psychiatr 1931, 136: 596-629.

26. Piotrowski Z. The Rorschach inkblot method in organic disturbances of the central nervous system. J Nerv Ment Dis 1937, 86: 525-537.

27. Prado GF. Estudo das alterações eletrencefalográficas em pacientes aidéticos com ou sem complicações secundárias. Tese de Mestrado, Escola Paulista de Medicina. São Paulo, 1991.

28. Prado GF, Silva AB, Lima JGC. Electroencephalogram (EEG) base rhythm in AIDS patients. Arq Neuropsiquiatr 1993, 51: 169-174.

29. Price RW, Brew B, Sidtis J, Rosenblum M, Scheckk AC, Cleary P, The brain in AIDS: central nervous system HIV-1 infection and AIDS dementia complex. Science 1988, 239: 586-591.

30. Pulliam L, Herndier BG, Tand NM, McGrath MS. Human immunodeficiency virus-infected macrophages produce soluble factors that cause histological and neurochemical alterations in cultured human brains. J Clin Invest 1991, 87: 503-512.

31. Riedel RR, Helmstaedter C, Bülau P, Durwen HF, Brackmann H, Fimmers R, Clarenbach P, Miller EN, Bottcher M. Early signs of cognitive deficits among human immunodeficiency virus-positive hemophiliacs. Acta Psychiatr Scand 1992, 85: 321-326.

32. Schnurbus R, Konneke J, Scheuler W, Kubicki ST, Henkes H, Girke W, Bienzle U. Comparison of EEG findings in HIV-infected and non-infected patients in out-patients and in-patients follow-ups. $V^{E}$ Conférence linternationale sur le SIDA. Montreal, 1989. Abregés. Montreal, 1989, p 462.

33. Smith T, Jakobsen J, Gaub J, Helweg-Larsen S, Trojaborg W. Clinical and electrophysiological studies of human immunodeficiency virus-seropositive men without AIDS. Ann Neurol 1988, 23: 295-297.

34. Tinuper P, De Carolis P, Galeotti M, Baldrati A, Sacquegna T, Gritti FM. Electroencephalography and HIV infection. Lancet 1989, 1: 554 